\title{
PENGOLAHAN LIMBAH CAIR TAHU MENGGUNAKAN TANAMAN KENAF (Hibiscus cannabinus L.) UNTUK MENURUNKAN KADAR AMONIUM DAN BOD PADA BED EVAPOTRANSPIRASI
}

\author{
TOFU WASTEWATER TREATMENT USING KENAF (HibiscuS \\ cannabinus L.) FOR DECREASING AMMONIUM AND BOD ON \\ BED EVAPOTRANSPIRATION
}

\author{
Firda Lutfiatul Fitria ${ }^{1}$ dan Sarwoko Mangkoedihardjo ${ }^{1}$ \\ 1) JurusanTeknik Lingkungan, Fakultas Teknik Sipil dan Perencanaan, Institut \\ Teknologi Sepuluh November, Kampus ITS Sukolilo Surabaya 60111 \\ Email : firdafitria.anas@gmail.com
}

\begin{abstract}
Abstrak
Industri tahu merupakan salah satu penghasil limbah cair. Limbah ini apabila tidak dikelola dengan baik akan mengakibatkan permasalahan lingkungan. Fitotretmen adalah salah satu teknologi yang memanfaatkan tumbuhan untuk mengurangi polutan zat pencemar organik maupun anorganik di dalam tanah, sedimen, atau air. Tanaman kenaf (Hibiscus cannabinus L.) dapat digunakan dalam proses fitotretmen karena mampu mengurangi zat pencemar. Penelitian ini bertujuan untuk menentukan penurunan kadar amonium dan BOD dalam pengolahan limbah cair tahu menggunakan tanaman kenaf. Pada penelitian ini digunakan bed evapotranspirasi dengan sistem batch. Variabel yang digunakan adalah varietas jenis tanaman kenaf (KR 12 dan KR 15) dan konsentrasi limbah cair tahu 75\% dan 50\% (kadar amonium sama). Penelitian ini dilakukan selama 28 hari. Efisiensi removal tertinggi untuk penurunan kadar amonium pada adalah Kenaf 15 limbah cair tahu $50 \%$ adalah $99,58 \%(42,093 \mathrm{mg} / \mathrm{L}$ menjadi $0,178 \mathrm{mg} / \mathrm{L})$. Efisiensi removal tertinggi untuk penurunan kadar BOD adalah Kenaf 15 limbah cair tahu 75\% yaitu 96,59\% (3371,25 menjadi 115,03 mg/L).
\end{abstract}

Kata kunci: Kenaf, amonium dan BOD

\section{Abstract}

Tofu Industry generates large amount of wastewater. If the wastewater is not properly managed it would lead to environmental problems. Phytotreatment is one of technologies that use plants to reduce organic pollutants and inorganic contaminants in soil, sediment, or water. Kenaf (Hibiscus cannabinus L.) can be used in the process of phytotreatmet because it can reduce the contaminants. This study aims to determine decreased levels of ammonium and BOD using Kenaf for tofu wastewater treatment. This study carried out using evapotranspiration bed in a batch system. The variables used were varieties of kenaf plant species (KR 12 and $K R$ 15) and the concentration of wastewater out $75 \%$ and $50 \%$ which has the same rate of ammonium. This study was conducted over 28 days. The highest removal efficiency for the decreased levels of ammonium was Kenaf 15 in wastewater $50 \%$ at day 28 (allowance ammonium) 99,58 \% (42,093 $\mathrm{mg} / \mathrm{L}$ to 0,178 $\mathrm{mg} / \mathrm{L}$ ). The highest removal efficiency for reduced levels of BOD were Kenaf 15 in tofu wastewater $75 \%$ at day 28 which were $96,59 \%(3371,25 \mathrm{mg} / \mathrm{L}$ to $115,03 \mathrm{mg} / \mathrm{L})$.

Keywords: Kenaf, ammonium dan BOD 


\section{PENDAHULUAN}

Industri tahu merupakan usaha di bidang pangan yang banyak terdapat di Indonesia. Proses pembuatan tahu tersebut menghasilkan limbah cair yang apabila tidak dikelola dengan baik maka dapat mengakibatkan permasalan lingkungan. Limbah cair tahu mengandung zat pencemar atau polutan organik sangat tinggi yang dapat mengakibatkan pencemaran lingkungan (Ratnani, 2011). Limbah cair industri tahu yang dibuang langsung ke sungai tanpa IPAL (Instalasi Pengolahan Air Limbah) akan mengakibatkan menurunnya kualitas air dan daya dukung lingkungan perairan. Hal tersebut mempengaruhi kondisi perairan sehingga berdampak pada organisme di dalam air. Wulandari dkk. (2014) menjelaskan bahwa hasil perhitungan indeks keanekaragaman jenis hewan makrobenthos yang didapatkan di Sungai Elo yang tercemar limbah cair tahu adalah 0,53 yang menunjukkan dalam komunitas tersebut terjadi tekanan dan stress.

Limbah cair industri tahu pada umumnya memiliki karakteristik berupa $\mathrm{pH}, \mathrm{COD}$ (Chemical Oxygen Demand), BOD (Biological Oxygen Demand), amonia, dan nitrat yang masih melebihi baku mutu air limbah (Puspayana dan Damayanti, 2013). Karakteristik limbah cair tahu mempunyai suhu berkisar $37-45^{\circ} \mathrm{C}$; $\mathrm{BOD}_{5}$ 6.000-8.000 mg/L dan COD 7.500-14.000 mg/L. Komponen terbesar dari limbah cair tahu yaitu protein (N-total) sebesar 226,06- 434,78 mg/l (Kaswinarni 2007). Menurut Suganda, dkk. (2014) hasil uji $\mathrm{pH}$, konsentrasi ammonia $\left(\mathrm{NH}_{3}\right)$ dan nitrat $\left(\mathrm{NO}_{3}\right)$ limbah cair tahu yaitu, 3,71; $27,99 \mathrm{mg} / \mathrm{L}$; dan $65,89 \mathrm{mg} / \mathrm{L}$. Karakteristik limbah cair tersebut tidak memenuhi baku mutu PP No. 82 Tahun 2001 dan Peraturan Gubernur Jawa Timur No. 72 Tahun 2013. Oleh karena itu sebelum limbah cair tahu dibuang ke badan air perlu diadakan pengolahan terlebih dahulu.

Fitotretmen merupakan teknologi menggunakan tumbuhan yang dapat mengurangi zat pencemar organik maupun anorganik di lingkungan. Materi organik dikuantitaskan sebagai BOD dan COD sedangkan materi anorganik adalah amonium, logam berat dan yang lainnya. Pemanfaatan tanaman ini adalah mentransfer, atau mendegradasi polutan dalam tanah, sedimen, atau air. Pemanfaatan tumbuhan terestial lebih efektif dari pada tumbuhan air. Tumbuhan terestial mempunyai akar yang lebih panjang dan besar dari pada tumbuhan air. (Mwegoha et al, 2008). Tumbuhan atau tanaman dari penelitian fitoremediasi dapat digunakan untuk fitotreatmen. Efektifitas proses fitotretmen sangat dipengaruhi oleh jenis dan konsentrasi kontaminan serta tanaman yang digunakan (Hardiani, 2009). Keunggulan menggunakan tumbuhan ini efektif, murah dan ramah lingkungan (Mwegoha et al, 2008).

Tanaman kenaf (Hibiscus cannabinus L.) merupakan tanaman komersial yang memiliki potensi ekonomi penting antara lain produksi kertas, bahan material bangunan, dan tekstil. Tanaman kenaf memiliki kemampuan adaptasi yang baik terhadap iklim dan tanah, toleran terhadap garam, tetapi sensitif terhadap hilangnya air. Pada penelitian terdahulu didapatkan hasil bahwa tanaman kenaf toleran terhadap bahan pencemar. Penelitian Samudro dan Mangkoedihardjo (2014) menunjukkan bahwa tanaman kenaf mampu mereduksi bahan organik dan logam berat.

Latar belakang yang telah disampaikan menjelaskan perlu adanya penelitian tanaman kenaf untuk pengolahan limbah cair tahu. Pada penelitian ini diharapkan dapat menurunkan konsentrasi amonia dan konsentrasi BOD yang tinggi atau rendah. Penelitian ini dapat memberikan informasi pemanfaatan tanaman kenaf sebagai tanaman alternatif dalam proses pengolahan limbah cair tahu. Hasil penelitian ini diharapkan dapat menjadi salah satu alternatif pengolahan limbah cair tahu yang efektif, murah, dan ramah lingkungan

\section{METODA}

Pelaksanaan penelitian menggunakan variasi antara lain jenis varietas tanaman kenaf (KR 12 dan KR15) dan variasi kadar limbah cair tahu (75\% dan 50\%) dengan kadar ammonium yang 
sama. Umur kenaf yang digunakan adalah 45 hari. Sistem reaktor yang digunakan pada penelitian ini adalah sistem bed evapotranspirasi dan jenisnya adalah Batch. Penelitian dilakukan secara triplo. Prosedur pelaksanaan kegiatan penelitian dari setiap tahapan adalah sebagai berikut :

\section{Tahap Persiapan}

Hal yang dilakukan pada tahap ini adalah pembibitan tanaman, dilakukan di rumah kaca. Tahap dan proses pembibitan dilakukan dengan:

1. Mengambil bibit di BALITTAS (Balai Tanaman Pemanis dan Serat) Kota Malang.

2. Memilih bibit yang baik, yaitu dengan cara merendam bibit di dalam wadah yang berisi air lalu dipisahkan antara bibit yang tenggelam dan mengapung. Bibit yang tenggelam di dasar digunakan sebagai bibit untuk menamam tanaman kenaf.

3. Menamam bibit pada kantong plastik yang berisi media tanah taman dan pupuk dengan perbandingan $1: 1$.

4. Disiram setiap hari menggunakan air PDAM dan diamati pertumbuhannya selama 1-2 minggu selama masa perkecambahan dan tunas. Kemudian Tanaman Kenaf dipindah tanamkan pada polybag.

\section{Tahap Uji Analisis Pendahuluan}

Tahap pengujian awal ini untuk uji konsentrasi amonium, BOD dan COD pada limbah cair tahu. Limbah tersebut diambil dari industri tahu di Jl. Kedung Tarukan Surabaya. Kemudian limbah cair tahu tersebut digunakan pada Range Finding Test tanaman kenaf di tahap pengujian berikutnya.

\section{Tahap Range Finding Test (RFT)}

Range finding test dilakukan untuk mengetahui kemampuan tanaman menyerap polutan yang terkandung dalam limbah limbah cair tahu pada konsentrasi tertentu. RFT ini dilakukan pada konsentrasi: $25 \% \mathrm{v} / \mathrm{v}, 50 \% \mathrm{v} / \mathrm{v}, 75 \% \mathrm{v} / \mathrm{v}$, dan $100 \%$ v/v. RFT menggunakan sistem SSFWetlands. Sistem yang menggunakan tanaman makrophyta yang akarnya tenggelam biasanya digunakan untuk lahan basah buatan tipe aliran bawah permukaan (Subsurface Flow Wetlands) SSF-Wetlands.

\section{Tahap Uji Fitotreatment}

Reaktor dioperasikan sesuai variasi penelitian yang telah ditentukan sebelumnya. Secara detail pelaksanaan uji fitortreatmen adalah sebagai berikut :

1. Reaktor uji fitotreament sesuai variabel.

2. Pada reaktor uji fitoremediasi (Gambar 1) akan dialirkan limbah cair tahu sesuai hasil konsentrasi RFT. Reaktor penelitian menggunakan bed evapotranspirasi dengan sistem batch.

3. Pengujian parameter dilakukan 7 hari sekali selama 28 hari.

4. Pengambilan sampel air dari pipa yang dipasang di reaktor bagian bawah.

5. Masing-masing reaktor diisi 5 tanaman kenaf dan diisi 6 liter limbah cair tahu.

6. Limbah cair tahu $75 \%$ dan $50 \%$ dengan kadar amonium yang sama. Dengan menambahkan $\mathrm{NH}_{4} \mathrm{Cl} 250 \mathrm{mg}$

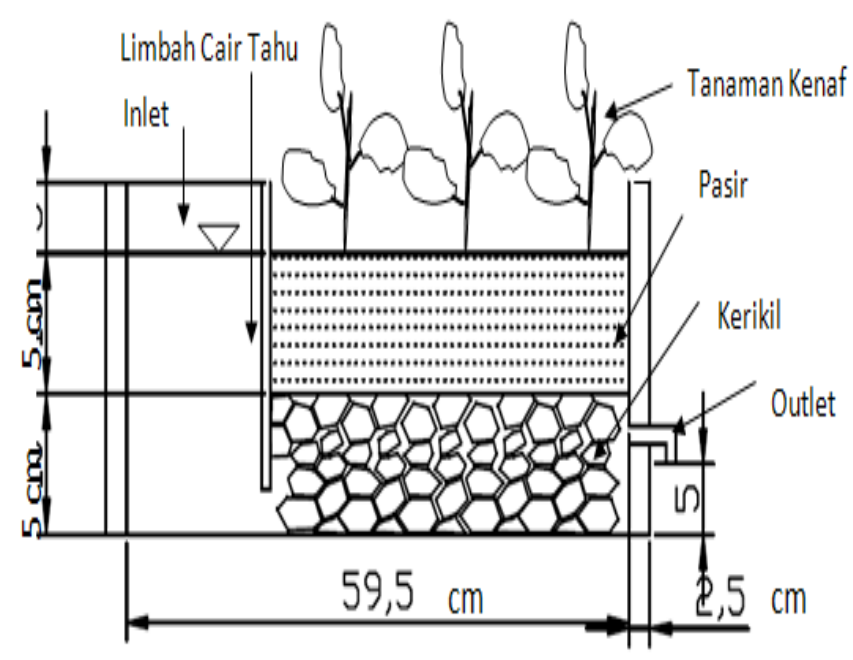

Gambar 1. Reaktor Uji Fitotreatment

Pelaksanaan analisis parameter

- Analisis Amonium 
Analisis ini menganalisa kadar amonium limbah cair tahu. Metode yang digunakan adalah metode Nessler.

\section{- Analisis BOD}

Uji analisis BOD digunakan untuk mengetahui besar kadar kebutuhan oksigen biologis. Analisis ini menggunakan metode 5 days BOD test.

\section{Tahap Analisis Data dan Pembahasan}

Data hasil pengamatan ditampilkan dalam bentuk grafik dan dianalisis dengan rancangan acak lengkap menggunakan Anova (Analysis of Variance) taraf 5\% kemudian dilanjutkan uji BNT. Berdasarkan analisis data maka didapatkan data yang dicari untuk membuat pembahasan.

\section{HASIL DAN PEMBAHASAN}

BALITTAS merupakan balai yang melakukan beberapa kegiatan penelitian (genetika, morfologi, fisiologi, ekologi, entomologi, dan pitofatologi), pembenihan dan menghasilkan teknologi yang berkaitan dengan tanaman tembakau, serat dan minyak industri. Balai ini memiliki 15 varietas tanaman kenaf dalam rangka usaha meningkatkan produksinya yaitu KR1, KR2, KR3, KR4, KR5, KR6, KR7, KR8, KR9, KR10, KR11, KR12, KR13, KR14, dan KR15 (BALITTAS, 2015). Semua varietas tersebut memiliki keunggulan dan kelebihan masing-masing. Salah satu varietas terbaik adalah KR12 yang memiliki kekuatan serat yang baik, moderat terhadap jasa, rentan terhadap nematode air, dan tahan terhadap genangan air. Sedangkan varietas lain adalah KR15 memiliki keunggulan pada umur panen, grade serat, kekuatan serat, kehalusan serat, reneamen serat, dan produktifitas hasil. Tanaman kenaf mampu beradaptasi pada berbagai jenis tanah tetapi paling sesuai adalah tanah yang subur, remah dan lempung berpasir yang mengandung humus. Tanaman ini memiliki keungulan dapat ditanam di lahan kritis (Hidayati, 2009).

Tanaman kenaf adalah tumbuhan dikotil yang termasuk genus Hibiscus dan family Malvaceae.
Tanaman ini merupakan herbaceous anual (tanaman tahunan) atau bineal, tinggi sampai 1,5 $-3,5 \mathrm{~m}$. Diameter batang tanaman kenaf adalah 1-2 cm, umumnya tidak selalu bercabang. Panjang daun dapat mencapai $10-15 \mathrm{~cm}$, bentuk daun bervariasi. Diameter bunga adalah 8-15 $\mathrm{cm}$, warna bunga bermacam-macam yaitu putih, kuning, atau warna ungu, ketika bunga warna putih atau kuning pada bagian dalam atau pusat warna tetap keunguan. Buah berbentuk kapsul dengan diameter $2 \mathrm{~cm}$ di dalam kapsul terdapat beberapa biji (Saba dkk., 2015).

Bibit Tanaman Kenaf diambil dari Balai Tanaman Pemanis dan Serat (BALITAS) berada di Jl. Karangploso Malang. Tanaman kenaf yang digunakan adalah varietas KR 12 dan KR 15 . Kedua varietas tersebut adalah varietas unggul. Tanaman kenaf dikembangbiakkan melalui biji. Biji kenaf berukuran $0,5 \mathrm{~cm}$ dapat dilihat pada Lampiran B. Tahapan pembibitan tanaman kenaf dilakukan dalam kantong plastik yang berisi kompos. Masing-masing kantong plastik ditanami 2-3 bibit. Hal ini diharapkan perkecambahan kenaf dapat optimal.

Perkecambahan tanaman kenaf adalah 3-8 hari. Kemudian tanaman kenaf umur 14 hari dipindah tanamkan ke polybag yang berisi tanah tanaman dan kompos. Hal ini diharapkan pertumbuhan kenaf dapat optimal. Tinggi tanaman Kenaf KR 12 dan KR 15 umur 14 hari adalah $7 \mathrm{~cm}$ dan 12 cm. Jumlah daun tanaman kenaf KR 12 dan KR 15 umur 14 hari adalah 2 helai daun. Tanaman disiram setiap hari menggunakan air PDAM. Dari hasil pengamatan selama 14 hari tersebut menunjukkan perkecambahan dan pertumbuhan tanaman Kenaf KR 15 lebih cepat dari pada tanaman Kenaf KR 12.

Penelitian pelaksanaan uji fitotretmen dilakukan selama 28 hari. Masa generatif kenaf sampai dengan 90 hari. Pada umur 92 hari tanaman kenaf berbunga.Tanaman yang digunakan adalah tanaman Kenaf KR 12 dan KR 15 dengan 45 hari. Uji fitotretmen dilakukan selama 28 hari karena agar tetap pada masa generatifnya. Pada umur kenaf 45 hari kemudian dilakukan perlakuan selama 28 hari hingga umur kenaf 72 hari. 
Pengamatan parameter dilakukan selama 7 hari sekali karena diharapkan semua tanaman sudah mengalami perubahan bentuk seperti bertambahnya daun dan bertambah panjang.

Reaktor yang digunakan terbuat dari semen dan terdapat kran air. Media tanaman berupa kerikil dan pasir. Tanah pasir selain miskin akan hara fosfor juga miskin hara N. Nitrogen yang tersedia dalam tanah dalam bentuk $\mathrm{NO}_{3}{ }^{-}$dan $\mathrm{NH}_{4}{ }^{+}$ seringkali hilang terlarut karena tidak terikat pada struktur tanah (Saptiningsih, 2007). Penggunaan media pasir diharapkan kebutuhan $\mathrm{N}$ kenaf dapat diambil dari limbah cair tahu. Tipe tanah seperti ini meskipun sulit untuk menahan air, tetapi mempunyai aerasi dan drainase yang baik. Media kerikil digunakan untuk penyangga. Masing-masing reaktor diisi 5 tanaman kenaf.

Limbah cair tahu dihasilkan dari proses pembuatan tahu. Proses pembuatan tahu adalah pencucian, perendaman, pemasakan, penyaringan, pengendapan, pembuangan cairan atau pengepresan, dan pencetakan (Setiawan dan Rusdjijati, 2014). Limbah cair tahu diambil di JL. Kedung Tarukan Surabaya. Hasil RFT limbah cair tahu yang digunakan adalah $75 \%$ dan $50 \%$ dengan konsentrasi amonium (Tabel.1). Masing-masing reaktor diisi 6 liter limbah cair tahu. Hal ini berdasarkan ukuran media reaktor yang berukuran $10 \mathrm{~cm}$ karena sistem yang dipakai SSF-Wetland.

Tabel 1. Uji Fitotretmen Limbah Cair Tahu

Parameter Limbah75\%(mg/L) Limbah 50\%(mg/L)

\begin{tabular}{lrr}
\hline Amonium & 42.09 & 42.1 \\
BOD & 3371.25 & 2247.5 \\
\hline
\end{tabular}

Reaktor yang digunakan ialah sistem reed bed atau bed evapotranspirasi. Desain implementasi dari bed evapotranspirasi, terdiri dari media kerikil dan pasir serta lapisan tanah atas untuk menanam tumbuhan. Evapotranspirasi potensial (ETP) merupakan jumlah air yang ditranspirasikan dalam satuan unit waktu oleh tanaman yang menutupi tanah secara keseluruhan dengan ketinggian seragam, tidak pernah kekurangan air, dan tidak terserang hama penyakit. Evapotranspirasi dapat diinterpretasi sebagai kehilangan air oleh tanaman yang diakibatkan faktor klimatologis (Rachmaulin dan Mangkoedihardjo, 2013).

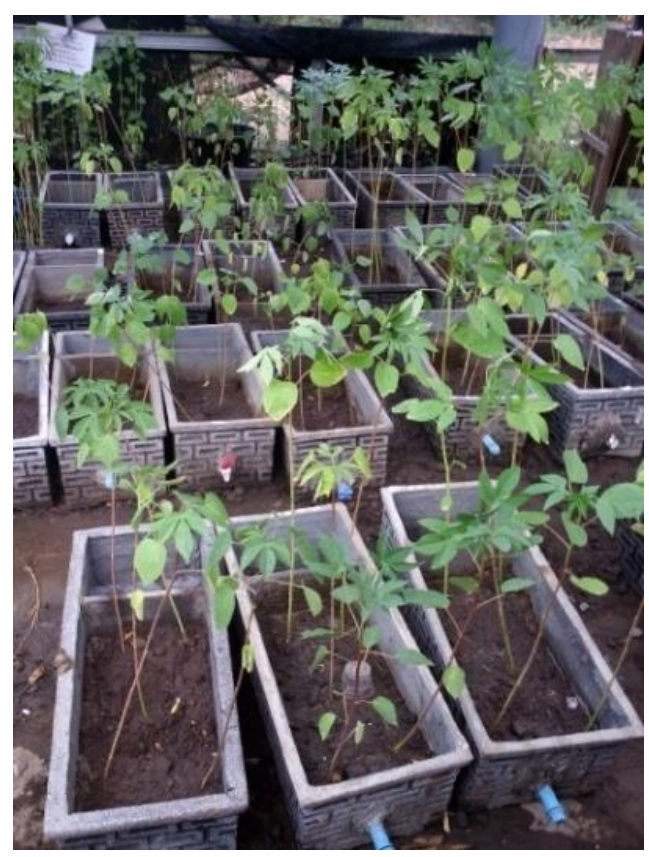

Gambar 2. Uji Fitotreatmen

\section{Analisis Amonium}

Tanaman kenaf mampu bertahan hidup pada kondisi konsentrasi amonium diatas baku mutu. Hasil yang dituangkan pada Gambar 4.3 menunjukkan adanya removal pada reaktor perlakuan dalam waktu 7, 14, 21, dan 28 hari. Removal tertinggi pada perlakuan 28 hari. Pada perlakuan limbah $75 \%$ removal tertinggi pada reactor Kenaf 15 umur 45 hari yaitu $99.08 \%$ adalah $0.389 \mathrm{mg} / \mathrm{L}$. Penyisihan amonium dapat disebabkan senyawa $\mathrm{N}$ tersebut digunakan tanaman dan mikroorganisme untuk biosintesis sel baru. Mikroorganisme dapat memanfaatkan nitrogen untuk sintesis sel mikroba, merubah nitrogen dan mengurangi kandungan nitrogen di lingkungan (Tang, 2010). 


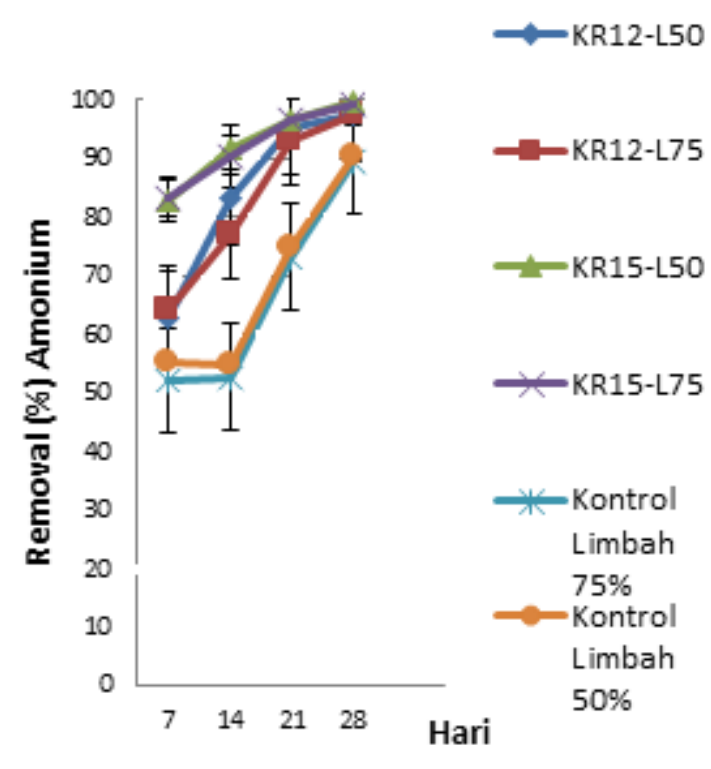

Gambar 3. Removal Amonium

Konsentarsi amonium Uji Anova taraf signifikansi $5 \%$ untuk kadar amonium reaktor ulangan (triplo) diperoleh nilai $\mathrm{P}(0,00)>0,05$. Hal ini menunjukkan bahwa pemberian limbah cair tahu pada reaktor ulangan tidak berpengaruh sangat nyata terhadap kadar amonium. Berdasarkan dengan uji Anova taraf signifikansi $5 \%$ untuk rerata kadar amonium perlakuan diperoleh nilai $\mathrm{P}(0,00)<0,05$. Hal ini menunjukkan bahwa pemberian limbah cair tahu pada reaktor perlakuan berpengaruh sangat nyata terhadap rerata kadar amonium. Pada Hasil uji BNT menunjukkan bahwa kadar amonium pada pemberian limbah cair tahu pada reaktor perlakuan berbeda sangat nyata dengan kontrol. Hal ini diduga karena reaktor kontrol tidak terdapat tanaman kenaf sehingga tidak ada penyerapan amonium oleh tanaman kenaf.

Pada reaktor kontrol terjadi removal amonium hal ini dapat dikarenakan adanya degradasi amonium oleh mikroorganisme. Amoniun akan didegradasi menjadi nitrat (nitrifikasi). Nitrifikasi merupakan proses pengubahan $\mathrm{NH}_{4}{ }^{+}$ menjadi $\mathrm{NO}_{3}{ }^{-}$. Proses degradasi amonium tebentuk nitrit. Suganda, dkk. (2014) menjelaskan bahwa menjelaskan bahwa senyawa nitrit merupakan senyawa yang tidak stabil dan mudah teroksidasi dalam proses nitrifikasi dan membentuk nitrat. Selama nitrit terbentuk dengan cepat nitrit akan dioksidasi menjadi nitrat oleh bakteri nitrobacter. Nitrifikasi merupakan proses pengubahan $\mathrm{NH}_{4}{ }^{+}$menjadi $\mathrm{NO}_{3}{ }^{-}$. Pada reaktor bed evapotranspirasi terjadi kehilangan air secara klimatologis. Amonium dalam air akan terjadi kesetimbangan berupa ion $\mathrm{NH}_{4}^{+}$dan sebagian lagi berupa $\mathrm{NH}_{3}$ bebas. Dijelaskan Limbong (2005) bahwa di dalam air sebagian besar amoniak akan terionisasi menjadi ion $\mathrm{NH}_{4}{ }^{+}$ dan sebagian lagi berupa $\mathrm{NH}_{3}$ bebas. Sehingga pada reaktor bed evapotranspirasi, amonium dapat terlepas menjadi gas amonia $\left(\mathrm{NH}_{3}\right.$ bebas).

Hasil perlakuan pada kontrol limbah $75 \%$ dan $50 \%$ pada 14 hari hampir tidak terjadi removal amonium yaitu $51,96 \%(20,22 \mathrm{mg} / \mathrm{L})$ menjadi $52,71 \%(19,91 \mathrm{mg} / \mathrm{L})$ dan 55,05\% (18,92 mg/L) menjadi 54,96\% (18,96 mg/L). Hal ini dapat diduga proses terbentuknya amonium karena perombakan materi organik (amonifikasi), penyisihan amonium (nitrifikasi) dan penyisihan amonium yang terlepas sebagai $\mathrm{NH}_{3}$ bebas hampir seimbang. Amonifikasi adalah proses perubahan senyawa $\mathrm{N}$-organik secara enzimatik menjadi senyawa amonium $\left(\mathrm{NH}_{4}^{+}\right)$dengan bantuan mikroorganisme (Limbong, 2005). Pada kontrol $75 \%$ dan $50 \%$ pada 28 hari removal amonium tinggi yaitu $89,43 \%(4,45 \mathrm{mg} / \mathrm{L})$ dan 90,26\% (4,1 mg/L). Penyisihan amonium karena adanya nitrifikasi (Suganda dkk., 2014) dan amonium yang terlepas sebagai $\mathrm{NH}_{3}$ bebas (Limbong, 2005).

Pada semua reaktor perlakuan tanaman kenaf terjadi penyisihan amonium karena adanya nitrifikasi, terjadi kesetimbangan amonium menjadi gas amoniak, dan penyerapan oleh tumbuhan. Adanya tanaman mampu memicu terjadinya proses nitrifikasi, dimana amonium diubah menjadi nitrat untuk kebutuhan nutrisi $\mathrm{N}$ bagi tanaman (Boudsocq, dkk., 2012). Hasil uji BNT menunjukkan bahwa kadar amonium pada pemberian limbah cair tahu pada reaktor perlakuan Kenaf KR 15 limbah 75\% tidak berbeda sangat nyata dengan reaktor perlakuan Kenaf KR 15 umur limbah 50\%. Prosentase removal Kenaf KR 15 umur 45 hari limbah 75\% dan $50 \%$ yaitu $99,08 \%$ dan $99,58 \%$. Reaktor dengan perlakuan limbah 50\% perlakuan 28 hari 
mempunyai removal lebih tinggi dari pada limbah $75 \%$ dimana perlakuan awal amonium memiliki kadar yang sama yaitu 42,093 mg/L. Hal ini menunjukkan penyerapan amonium oleh tanaman lebih efektif pada limbah 50\%. Pada reaktor terjadi degradasi materi organik menjadi amonium oleh organisme (amonifikasi). Materi organik pada limbah $75 \%$ lebih banyak dari pada perlakuan limbah 50\%. Materi organik dapat dilihat pada BOD awal. Dimana BOD awal limbah $75 \%$ dan $50 \%$ adalah $3371,25 \mathrm{ml} / \mathrm{L}$ dan $2247,5 \mathrm{ml} / \mathrm{L}$. Limbah $50 \%$ mengandung materi organik lebih sedikit maka dari itu removal amonium tertinggi yaitu pada perlakuan limbah $50 \%$.

Hasil uji BNT menunjukkan bahwa kadar amonium pada pemberian limbah cair tahu pada perlakuan 28 hari reaktor perlakuan Kenaf KR 15 umur 45 hari limbah 50\% berbeda sangat nyata dengan reaktor perlakuan Kenaf KR 12 umur 45 hari limbah $50 \%$. Prosentase reaktor perlakuan limbah 50\% pada reaktor Kenaf KR 15 umur 45 hari dan reaktor perlakuan Kenaf KR 12 umur 45 hari adalah $99,58 \%$ dan $97.53 \%$. Hal ini diduga pertumbuhan Kenaf KR 15 umur 45 hari lebih cepat dari pada Kenaf KR 12 umur 45 hari. Pertumbuhan yang cepat mengakibatkan pertumbuhan tanaman meningkat. Salah satunya adalah meningkatkan pertumbuhan panjang akar. Tumbuhan yang mempunyai perakaran yang meluas dan tergenang sehingga faktor penguapan yang lebih besar juga dapat menjadi faktor penyebab peningkatan pengolahan amonium.

Konsentrasi amonium bisa sangat rendah karena diserap oleh akar tanaman kenaf. Mekanisme fitotretmen removal amonium adalah rhizodegradasi dan fitodegradasi. Dimana pada mekanisme rhizodegradasi adalah adanya degradasi amonium oleh mikrorganisme pada rhizosfer atau daerah perakaran kenaf. Kemudian hasil degradasi amonium akan diserap oleh tanaman. Maka dari itu pada mekanisme ini terjadi simbiosis antara tanaman dan mikroorganisme. Mekanisme fitodegradasi yang terjadi pada penelitian ini yaitu degradasi amonium dalam bagian tanaman seperti akar batang dan daun. Amonium yang berupa ion dapat diserap langsung oleh tanaman. Widayat (2010) menjelaskan bahwa senyawa amonium dalam air digunakan tumbuhan untuk proses biosintesis untuk pembentukan sel baru.

Hasil uji fitotretmen tanaman kenaf dapat menyerap amonium sebagai polutan limbah cair tahu. Fitotretmen merupakan suatu pemanfaatan tumbuhan untuk pengolahan limbah yang biodegradable (Mangkoedihardjo, 2006). Pemanfaatan tumbuhan kenaf adalah untuk mengubah, menstabilkan, atau menghancurkan zat kontaminan menjadi kurang atau tidak berbahaya. Pemanfaatan tanaman adalah mengurangi zat pencemar di lingkungan termasuk zat pencemar organik maupun anorganik (Mwegoha dkk., 2008). Tumbuhan dapat bekerjasama dengan mikroorganisme dalam media (Artiyani, 2011). Upaya penggunaan tanaman ini untuk mengurangi konsentrasi limbah dan masalah-masalah pencemaran lingkungan baik secara ex-situ menggunakan kolam buatan atau reaktor maupun in-situ (langsung di lapangan) pada tanah atau perairan yang terkontaminasi limbah (Soetrisnanto dkk., 2012).

\section{Analisis BOD}

Peningkatan produksi tahu mengakibatkan kuantitas limbah cair yang dihasilkan sangat tinggi. Limbah tersebut mengandung polutan organik yang cukup tinggi serta padatan tersuspensi maupun terlarut yang akan mengalami perubahan fisika, kimia, dan biologi. Bahan baku tahu adalah kedelai, asam cuka, dan air. Limbah cair yang dihasilkan oleh industri pembuatan tahu sebagian besar adalah cairan kental yang terpisah dari gumpalan tahu yang disebut dengan air dadih (whey). Cairan ini mengandung kadar protein yang tinggi dan dapat segera terurai (Husni dan Esmiralda, 2010). Kedelai banyak mengandung protein atau senyawa-N. Maka dari itu diperlukan uji BOD untuk mengetahui kebutuhan oksigen yang diperlukan mikroorganisme untuk merombak materi organik limbah cair tahu.

Hasil pengamatan menununjukkan tanaman kenaf mampu bertahan hidup pada kondisi 
konsentrasi amonium diatas baku mutu. Limbah cair tahu pada uji awal mempunyai rasio BOD:COD awal adalah 0,78. Rasio tersebut merupakan zat pencemar yang biodegradabel sehingga teknik pengolahannya dapat menggunakan fitotretmen. Hasil data pada Gambar 4.5 menunjukkan adanya removal BOD pada reaktor perlakuan dalam waktu $7,14,21$, dan 28 hari. Removal tertinggi pada perlakuan 28 hari. Pada perlakuan limbah $75 \%$ removal tertinggi pada reaktor Kenaf KR 15 yaitu 96,59\% adalah $115,03 \mathrm{mg} / \mathrm{L}$.

Rasio BOD/COD setelah perlakuan limbah 75\% dan $50 \%$ pada reaktor Kenaf KR 15 umur 45 hari adalah 0,75 dan 0,65 . Setelah dilakukan uji fitotretmen rasio BOD:COD mengalami penurunan tetapi rasio tersebut masih merupakan zat pencemar biodegradabel. Dari hasil pengamatan tersebut menunjukkan setelah dilakukan uji fitotretmen nilai BOD dapat memenuhi baku mutu SK Gubernur Jatim No. 72 Tahun 2013 yaitu baku mutu BOD adalah 150 mg/L. Penyisihan kadar BOD dapat dilihat pada Gambar 4.

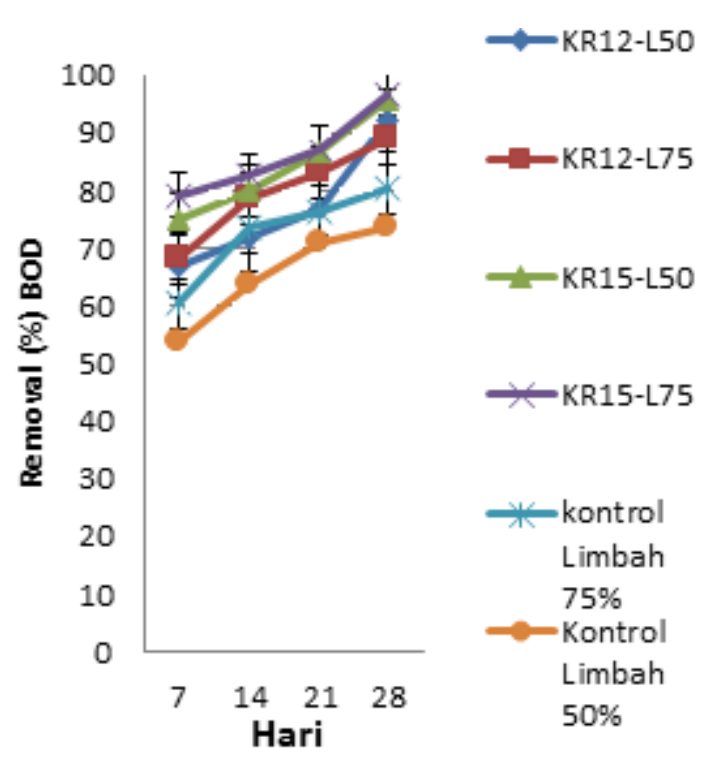

Gambar 4. Removal BOD

BOD menunjukkan jumlah oksigen yang dibutuhkan oleh mikroorganisme untuk menguraikan bahan-bahan organik yang terdapat dalam air limbah secara biologi. Semakin tinggi nilai BOD maka semakin banyak tingkat pencemaran bahan organik dalam perairan, sehingga semakin banyak jumlah oksigen yang dibutuhkan oleh mikroorganisme untuk mendegradasi bahan organik dan semakin sedikit jumlah oksigen yang tersedia/tersisa untuk kehidupan organisme di perairan. Uji analisis BOD bertujuan untuk menghitung kebutuhan mikroorganisme untuk mendegradasi zat organik melalui proses biokimia. Reaksi biologis untuk memecahkan bahan-bahan organik tersebut secara sempurna pada suhu $20^{\circ} \mathrm{C}$ sebenarnya dibutuhkan waktu lebih dari 20 hari, tetapi untuk prasktisnya diambil selama 5 hari (Kaur dkk., 2014).

Berdasarkan dengan uji Anova taraf signifikansi 5\% untuk rerata kadar BOD setiap perlakuan diperoleh nilai $\mathrm{P}(0,00)<0,05$. Hal ini menunjukkan bahwa pemberian limbah cair tahu pada reaktor perlakuan berpengaruh sangat nyata terhadap rerata kadar BOD. Hasil uji BNT menunjukkan bahwa kadar BOD pada pemberian limbah cair tahu pada reaktor perlakuan berbeda sangat nyata dengan kontrol.

Penyisihan BOD pada reaktor perlakuan dapat dikarenakan adanya mikroorganisme dalam rhizosfer tanaman kenaf. Tanaman mensuplai oksigen ke dalam air limbah melalui akar dan menambah jumlah oksigen terlarut dalam air limbah sehingga akan memacu kerja mikroorganisme dalam menguraikan senyawasenyawa organik pencemar (Purwanti, 2014).

Proses evapotranspirasi yang terjadi akan mendukung laju pengambilan unsur hara yang dibutuhkan dalam proses fotosintesis melalui mekanisme penyerapan air melalui bulu-bulu akarnya. Aktivitas fotosintesis yang tinggi, akan menghasilkan oksigen yang tinggi pula sehingga oksigen terlarut dalam limbah cair akan meningkat (Purwanti, 2014). Penguraian bahan organik secara biologis di alam, melibatkan bermacam-macam organisme dan menyangkut reaksi oksidasi dengan hasil akhir karbon dioksida $\left(\mathrm{CO}_{2}\right)$ dan air $\left(\mathrm{H}_{2} \mathrm{O}\right)$ (Salmin, 2005).

Oksigen akan digunakan oleh mikroorganisme untuk mendegradasi bahan organik menjadi anorganik, seperti $\mathrm{NO}_{3}{ }^{-}, \mathrm{NO}_{2}^{-}, \mathrm{H}_{2} \mathrm{O}$ dan lainnya. 
Kenaf akan menyerap unsur-unsur hara yang larut dalam air melalui akarnya. Penyerapan tersebut dilakukan oleh akar tumbuhan dimana juga terdapat mikroorganisme yang hidup bersimbiosa di sekitar akar. Mekanisme ini disebut dengan rhizhodegradasi. Semakin banyak jaringan akar dalam tanah, semakin luas zona rhizosfer yang tercipta, sehingga dapat menyerap material organik yang terdapat dalam limbah cair tahu dan berperan dalam proses penurunan konsentrasi BOD. Semakin lama waktu tinggal air limbah di dalam reaktor, maka semakin besar pula efisiensi penurunan kadar BOD yang dihasilkan. Hal ini berkaitan dengan perombakan materi organik oleh mikroorganisme dan penyerapan tanaman.

Keunggulan pemanfaatan tanaman kenaf sebagai pengolahan limbah cair tahu adalah teknologi efektif, murah dan ramah lingkungan. Pemanfaatan tumbuhan tidak memerlukan perlengkapan yang mahal, personal spesialis, dan lebih murah dari pada metode fisik kimia konvensional. Pemanfaatan tumbuhan terestial lebih efektif dari pada tumbuhan air. Tanaman kenaf merupakan tumbuhan terestial. Hal ini disebabkan tumbuhan terestial mempunyai akar yang lebih panjang dan besar dari pada tumbuhan air (Mwegoha dkk., 2008). Beberapa senyawa organik dapat di melewati membran tanaman. Senyawa yang memiliki berat molekul ringan dapat dapat di transfer dari tanah kemudian dilepaskan oleh daun melalui proses evapotranspirasi. Beberapa seyawa yang nonvolatile dapat didegradasi atau diubah menjadi senyawa tidak berbahaya melalui modifikasi enzimatis melalui proses fitodegradasi (Gerhardt dkk., 2009).

\section{Analisis Fisik Tanaman}

Pengukuran pertumbuhan tanaman kenaf (panjang tanaman dan jumlah daun) bertujuan untuk mengetahui respon spesifik tanaman kenaf terhadap paparan limbah cair tahu. Pertumbuhan vegetatif tanaman adalah pertumbuhan yang berhubungan dengan penambahan ukuran dan jumlah sel pada suatu tanaman. Dari hasil analisis fisik tanaman mampu hidup pada perlakuan dengan limbah cair tahu yang memiliki karakteristik amonium dan BOD lebih dari baku mutu.

Hasil penelitian menunjukkan respon spesik tanaman kenaf ditandai dengan meningkatnya panjang tinggi tanaman dan jumlah daun. kenaikan jumlah Hal ini dikarenakan limbah cair tahu mengandung nutrien seperti senyawa nitrogen yang dapat diserap tumbuhan. Nitrogen digunakan tumbuhan untuk pembentukan sel baru. Parameter yang diukur pada penelitian ini adalah tinggi tanaman dan jumlah daun. Tinggi tanaman merupakan ukuran tanaman yang sering diamati sebagai indikator pertumbuhan maupun sebagai parameter untuk mengukur pengaruh lingkungan atau perlakuan yang diterapkan karena tinggi tanaman merupakan ukuran pertumbuhan yang paling mudah dilihat pada Gambar 5.

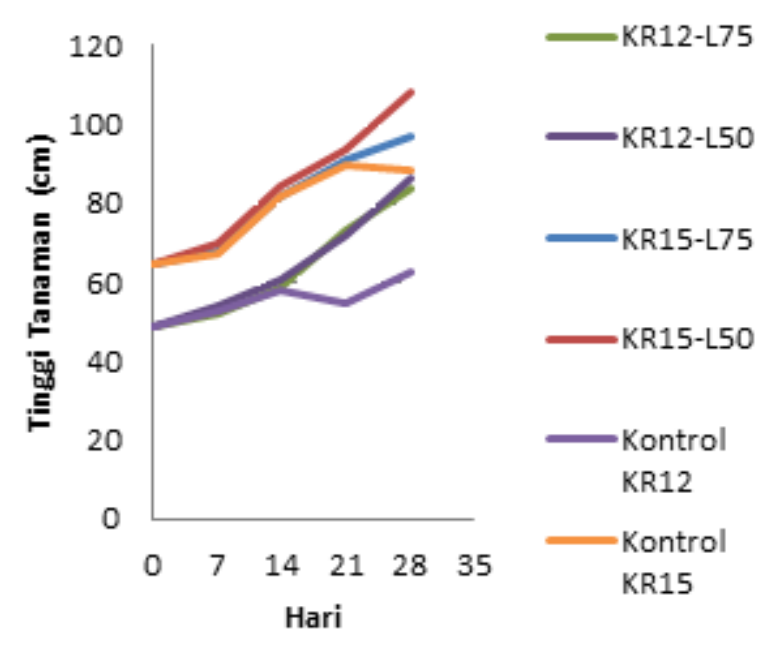

Gambar 5. Tinggi Tanaman Kenaf

Hasil pengamatan tinggi tanaman kenaf pada hari ke-28 dapat dilihat pada gambar 4.7. Pada reaktor perlakuan limbah $75 \%$ pada hari ke-28 menunjukkan tinggi daun Kenaf KR 12 dan Kenaf KR 15 adalah $84 \mathrm{~cm}$, dan $97 \mathrm{~cm}$. Pada perlakuan limbah 50\% menunjukkan tinggi tanaman Kenaf KR 12 dan Kenaf KR 15 adalah $87 \mathrm{~cm}$, dan $108 \mathrm{~cm}$. Hasil pengamatan tinggi tanaman pada reaktor kontrol yaitu Kenaf KR 12 dan Kenaf KR 15 adalah $63 \mathrm{~cm}$ dan $88 \mathrm{~cm}$. Pada hasil pengamatan tinggi tanaman didapatkan Kenaf KR 15 lebih besar dari pada Kenaf KR 12. 
Menurut BALITTAS pertumbuhan Kenaf KR 15 lebih besar dari pada Kenaf KR 12. Hasil pengamatan parameter tinggi tanaman didapatkan Kenaf KR 15 perlakuan limbah 50\% yang paling tinggi.

Parameter pertumbuhan vegetatif kedua yang diamati ialah jumlah daun. Pengamatan jumlah daun sangat diperlukan karena selain sebagai indikator pertumbuhan parameter jumlah daun juga diperlukan sebagai data penunjang untuk menjelaskan proses pertumbuhan yang terjadi.

Hasil pengamatan jumlah daun tanaman kenaf pada semua jenis perlakuan nampak tidak begitu jauh berbeda. Pada reaktor perlakuan limbah $75 \%$ pada hari ke-28 menunjukkan jumlah daun Kenaf KR 12 dan Kenaf KR 15 adalah 17 helai daun dan 18 helai daun. Pada perlakuan limbah 50\% menunjukkan jumlah daun Kenaf KR 12 dan Kenaf KR 15 adalah 17 helai daun dan 20 helai daun. Jumlah daun pada reaktor kontrol yaitu Kenaf KR 12 dan Kenaf KR 15 adalah 15 helai daun dan 18 helai daun. Hasil pengamatan jumlah daun didapatkan Kenaf KR 15 hari perlakuan limbah 50\% yang paling banyak.

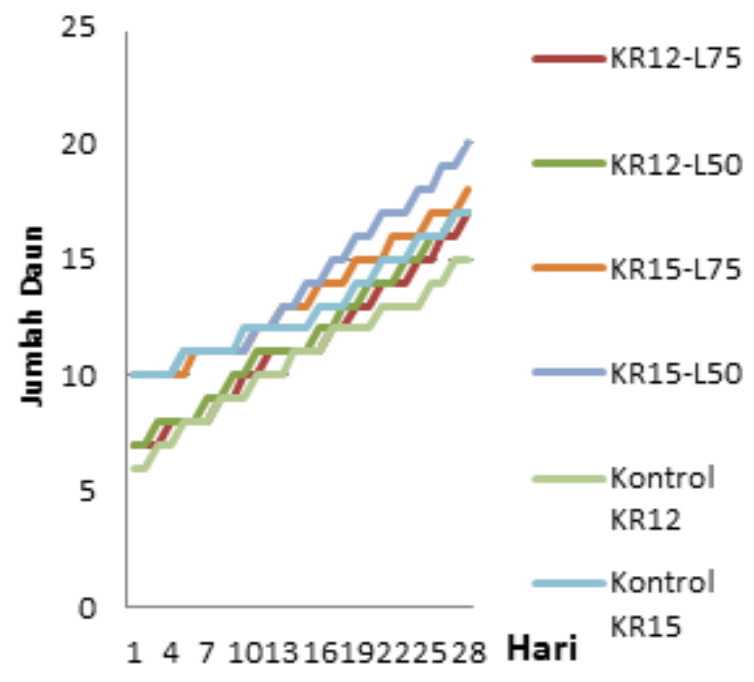

Gambar 6. Jumlah Daun Kenaf
Berdasarkan pengamatan fisik tanaman tampak bahwa ada perbedaan respon spesifik tanaman meliputi tinggi tanaman dan jumlah daun. Pada hasil pengamatan menujukkan KR 15 hari pada perlakuan limbah $50 \%$ memiliki jumlah daun yang paling banyak dan paling panjang tinggi tanamannya. Hal ini dapat dikarenakan adanya penambahan $\mathrm{N}$-anorganik. Hal ini dapat dikarenakan adanya penambahan $\mathrm{N}$-anorganik pada perlakuan limbah $50 \%$ sehingga tanaman Kenaf KR 15 lebih mudah menyerap Nanorganik untuk proses biosintesis sel baru untuk pertumbuhan tanaman. Hal ini merujuk pada Krismawati (2005) menjelaskan bahwa syarat pertumbuhan kenaf membutuhkan nitrogen sehingga dapat dengan cara menambahkan Nanorganik. Menurut Ekowati dan Nasir (2010) menjelaskan bahwa jumlah daun yang lebih banyak maka tempat terjadinya fotosintesis juga lebih banyak. Jika tinggi tanamannya lebih tinggi maka cahaya matahari yang didapatkan juga lebih banyak. Maka dari itu demikian diasumsikan respon spesifik tanaman Kenaf KR 15 lebih baik karena penyerapan unsur hara $\mathrm{N}$ dari zat pencemar limbah tahu dan proses fotosintesis lebih baik.

\section{Analisis pH}

Nilai pH air digunakan untuk mengekspresikan kondisi keasaman (konsentrasi ion hidrogen). $\mathrm{pH}$ dipengaruhi oleh ion $\mathrm{H}^{+}$dan ion $\mathrm{OH}^{-}$. Hal ini mempengaruhi metabolisme mikroorganisme yang akan mendegradasi bahan organik. $\mathrm{pH}$ air sangat mempengaruhi proses biokimiawi dalam air (Ratnani, 2011). Skala pH berkisar antara 114; kisaran nilai $\mathrm{pH}$ 1-7 termasuk kondisi asam, $\mathrm{pH}$ 7-14 termasuk kondisi basa, dan $\mathrm{pH} 7$ adalah kondisi netral. Nilai $\mathrm{pH}$ limbah cair tahu adalah sebesar 4,5-5. Pada penelitian uji fitotretmen mulai hari ke 28 nilai $\mathrm{pH}$ berkisar 7,4-7,5. Kisaran nilai $\mathrm{pH}$ tersebut dapat ditoleransi tanaman dan mikroorganisme. Menurut Ratnani (2011) bahwa kisaran nilai $\mathrm{pH}$ yang dapat ditoleransi tanaman dan mikroorganisme adalah 5-9. 


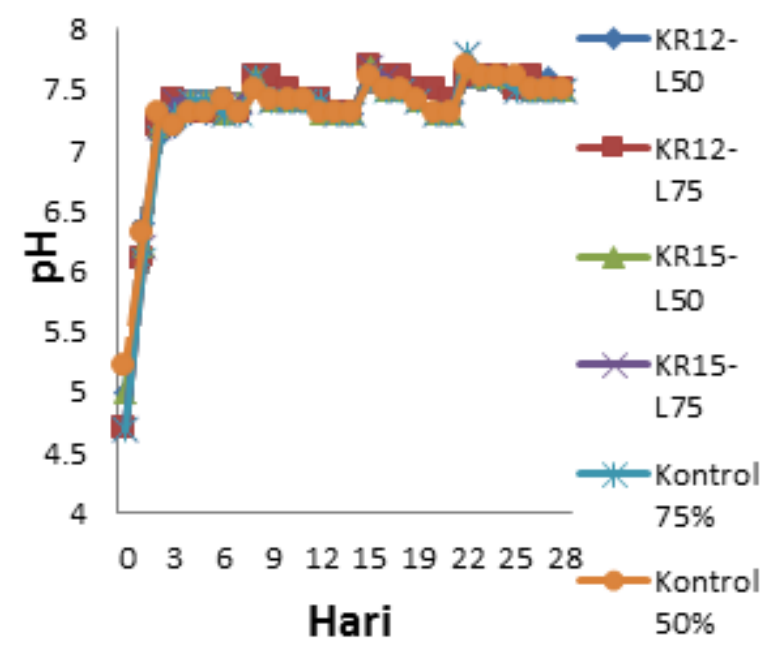

Gambar 7. Pengukuran pH

Hasil pengamatan menunjukkan adanya peningkatan $\mathrm{pH}$ yang signifikan pada hari ke-1 dan ke-2. Pada $\mathrm{pH}$ awal penelitian pada reaktor limbah $75 \%$ adalah 4,7. Pada reaktor perlakuan reaktor limbah 75\% Kenaf KR 12, Kenaf KR 15, dan kontrol adalah 6,1; 6,2 dan 6,2. Pada $\mathrm{pH}$ awal penelitian pada reaktor limbah 50\% adalah 5,1. Pada perlakuan limbah 50\% menunjukkan Kenaf KR 12, Kenaf KR 15 dan kontrol adalah 6,$2 ; 6,3$ dan 6,3. Pada hari ke-2 $\mathrm{pH}$ pada reaktor perlakuan maupun kontrol pada hasil pengamatan menujukkan $\mathrm{pH}$ netral. Pada perlakuan $75 \%$ menunjukkan Kenaf KR 12, Kenaf KR 15 dan kontrol hari ke-2 adalah 7,1;7,2 dan 7,1. Pada perlakuan 50\% menunjukkan Kenaf KR 12, Kenaf KR 15, dan kontrol pada hari ke-2 adalah 7,2;7,3 dan 7,2. Hal ini diduga bahwa pada reaktor terdapat pasir yang mengandung mineral atau ion-ion yang dapat menetralkan $\mathrm{pH}$ limbah cair tahu.

\section{Analisis Suhu}

Suhu mempengaruhi laju metabolisme, keseimbangan ionisasi, kecepatan transfer gas dan kelarutan substrat. Suhu juga mempengaruhi mikroorganime dengan suhu optimum organisme adalah $30^{\circ} \mathrm{C}$. Pada penelitian ini terlihat hasil pengukuran suhu mengalami fluktuatif. Hal ini dikarenakan kondisi cuaca pada hari pengamatan dan intensitas penyinaran matahari yang tidak tetap. Namun fluktuasi suhu harian tidak mencapai selisih yang terlalu besar. Pukul 06.00 suhu akan meningkat, pukul 14.00 suhu menurun dan pukul 20.00 suhu semakin konstan disebabkan energi matahari yang diterima akan semakin besar sesuai dengan sudut jatuh radiasi matahari. Hasil pengamatan suhu dapat dilihat pada Gambar 8.

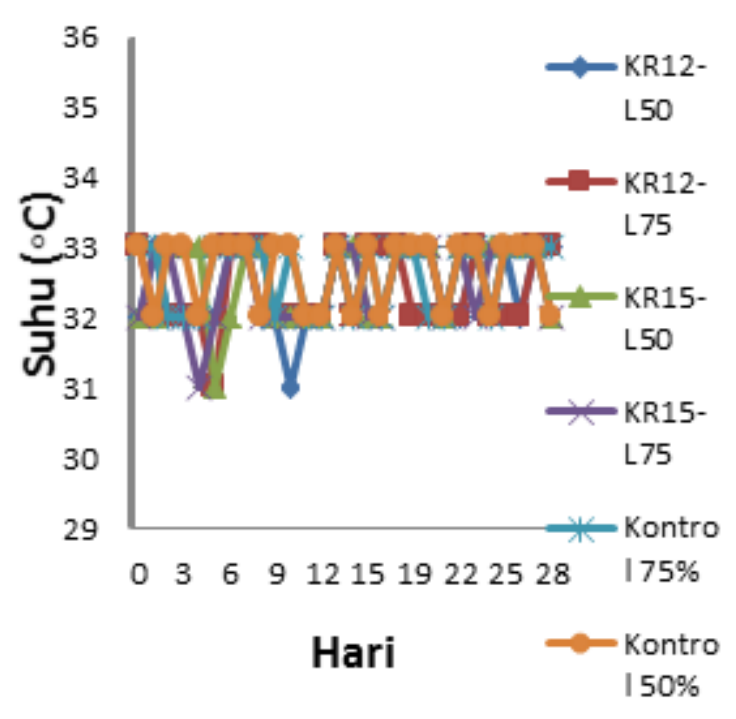

Gambar 8. Pengukuran Suhu

Perombakan materi organik oleh mikroorganisme sangat dipengaruhi oleh faktor lingkungan fisik seperti terbatasnya air dan suhu (temperatur). Hasil pengamatan suhu uji fitotretmen berfluaktuatif berkisar $31-33^{\circ} \mathrm{C}$. Pada kondisi tersebut aktifitas mikroorganisme masih dapat berlangsung dengan baik. Mikroorganisme berperan dalam proses nitrifikasi dan amonifikasi. Maka dari itu pengukuran parameter suhu penting dalam uji fitotretmen pada penelitian ini. Hasil pengamatan pada reaktor perlakuan dan reaktor kontrol limbah $75 \%$ suhu berkisar $31-33^{\circ} \mathrm{C}$. Hasil pengamatan pada reaktor perlakuan dan reaktor kontrol limbah juga \% suhu berkisar $31-33^{\circ} \mathrm{C}$. Hasil pengamatan setiap reaktor perlaukan dan reaktor kontrol tidak jauh berbeda. Hal ini diduga reaktor perlakuan dan reaktor kontrol berada pada tempat yang sama yaitu di green house. Hasil pengamatan parameter suhu yang tidak jauh berbeda maka diharapkan tidak mempengaruhi hasil pengamatan parameter amonium dan BOD. 


\section{KESIMPULAN}

Tanaman kenaf mampu menurunan kadar amonium dan BOD limbah cair tahu pada reaktor bed evapotranspirasi. Removal tertinggi kadar amonium pada tanaman Kenaf KR 15 pada limbah $50 \%$ adalah $99.58 \% \quad(42,093 \quad \mathrm{mg} / \mathrm{L}$ menjadi $0,178 \mathrm{mg} / \mathrm{L})$. Removal tertinggi BOD pada Kenaf KR 15 pada limbah $75 \%$ adalah 96,59\% (3371,25 menjadi 115,03 mg/L).

\section{DAFTAR PUSTAKA}

Artiyani, A. 2011. Penurunan Kadar N-Total dan P-Total pada Limbah Cair Tahu dengan Metode Fitoremediasi Aliran Batch dan Kontinyu Menggunakan Tanaman Hydrilla Verticillata. Jurnal Spectra, 9 (18): 9-14.

Balai Penelitian Tanaman Pemanis dan Serat (BALITTAS). $2015 . \quad$ Kenaf. http://balittas.litbang.pertanian.go.id.

Ekowati, D dan Nasir, M. 2011. Pertumbuhan Tanaman Jagung (Zea mays L.) Varietas Bisi-2 Pada Pasir Reject dan Pasir Asli di Pantai Trisik Kulonprogo. Jurnal Manusia dan Lingkungan, 18 (3): 220 - 231

Hardiani, H. 2009. Potensi Tanaman dalam Mengakumulasi Logam $\mathrm{Cu}$ pada Media Tanah Terkontaminasi Limbah Padat Industri Kertas. Balai Besar Pulp dan Kertas Bandung, 44 (1): 27 - 40.

Hidayati, Y. 2009. Kadar Hormon Auksin pada Tanaman Kenaf (Hibiscus cannabinus L.) Bercabang dan Tidak Bercabang. AGROVIGOR, 2(2):89-96.

Gerhardt, K.E., Huang, X.D., Glick, B.R., dan Greenberg, B. M. 2009. Review: Phytoremediation and rhizoremediation of organic soil contaminants: Potential and challenges. Plant Science, 176: 20-30.
Kaur, A., Ghosal, S., Shinver, N.M. dan Mohammad Zeeshan Alam Khan, M.Z.A. 2014. Recycling of Water: A Review on Wastewater Treatment. Internatiional Journal Of Pure \& Applied Bioscience, 2 (3): 318-326.

Krismawati ,A. 2005. Uji Adaptasi Varietas Dan Galur Kenaf (Hibiscus cannabinus L.) Di Lahan Pasang Surut Kalimantan Tengah. Jurnal Littri, 11 (3): 107 - 111.

Limbong. 2005. Pengolahan Limbah Cair Mengandung Amoniak dengan Gelumbung $\mathrm{CO}_{2}$. Tesis. UNDIP. Semarang.

Mangkoediharjo, S. dan Samudro, G. 2014. Research Strategy on Kenaf for Phytoremediation of Organic Matter and Metals Polluted Soil. Advances in Enviromental Biology, 8(17): 64-67.

Mwegoha, W. J. S. 2008. The Use of Phytoremediation Technology for Abatement Soil and Groundwater Pollution in Tanzania: Opportunities and Challenges. Journal of Sustainable Development in Africa, 10(1): 140-156.

Peraturan Gubernur Jawa Timur Nomor 72 Tahun. 2013. Baku Mutu Air Limbah Bagi Industri Dan/Atau Kegiatan Usaha Lainnya.

Purwanti, Elystia,S., dan Sasmita,A. 2014. Pengolahan Limbah Cair Pabrik Kelapa Sawit Dengan Metode Fitoremediasi Menggunakan Typha Latifolia. JOM FTEKNIK, 1 (2): 1-9.

Puspayana, D.R. dan Damayanti, A. 2013. Pengolahan Limbah Cair Tahu Menggunakan Membran Nanofiltrasi Silika Aliran Cross Flow untuk Menurunakan Kadar Nitrat dan Amonium. Institut Teknologi Sepuluh Nopember. Surabaya. 
Rachmaulin,S.H. dan Mangkoedihardjo,S. 2013. Pengaruh Waktu Pemaparan dan Jumlah Tumbuhan Terhadap Efisiensi Pengolahan Lindi Tpa Sidoarjo Menggunakan Scirpus grossus. Jurnal Teknik POMITS, 2(1):1-4.

Ratnani, R.D. 2011. Kecepatan Penyerapan Zat Organik pada Limbah Cair Industri Tahu dengan Lumpur Aktif. Momentum, 7(2): 18 - 24.

Saba, N., Jawaid, M., Hakeem, K.R., Paridah, M.T., Khalina, A., dan Alothman, O.Y. 2015. Potential of bioenergy production from industrial kenaf (Hibiscus cannabinus L.) based on Malaysian perspective. Renewable and Sustainable Energy Reviews, 42: 446-459.

Salmin. 2005. Oksigen Terlarut (DO) Dan Kebutuhan Oksigen Biologi (BOD) Sebagai Salah Satu Indikator Untuk Menentukan Kualitas Perairan. Oseana, 30 (3): 21 - 26

Saptiningsih, E. 2007. Peningkatan Produktivitas Tanah Pasir untuk Pertumbuhan Tanaman Kedelai dengan Inokulasi Mikorhiza dan Rhizobium. Bioma, 9(2): $58-61$.

Setiawan, A. dan Rusdjijati, R. 2014. Peningkatan Kualitas Biogas Limbah Cair
Tahu dengan Metode Taguchi. Prosiding SNATIF Ke -1. Universitas Muria Kudus, hal. 35-40

Suganda, R., Sutrisno, E., dan Wardana, I.R. 2014. Penurunan Konsentrasi Amonia, Nitrat, Nitrit dan COD dalam Limbah Cair Tahu dengan Menggunakan BiofilmKolam (Pond) Media Pipa PVC Sarang Tawon dan Tempurung Kelapa Disertai Penambahan Ecotru. Jurnal Teknik Lingkungan, 3(4): 1-8.

Tang, S., Q. Yang, H. Shang, T. Sun. 2010. Removal of Nitrate by Autosulfurotrophic Denitrifying Bacteria: Optimization, Kinetics and Thermodynamics Study. Fresenius Environmental Bulletin. 19(12b):3193-3198.

Widayat, W, Suprihatin, dan Herlambang, A. 2010. Penyisihan Amoniak Dalam Upaya Meningkatkan Kualitas Air Baku PDAMIPA Bojong Renged dengan Proses Biofiltrasi Menggunakan Media Plastik Tipe Sarang Tawon. JAI, 6(1):64-76.

Wulandari, A.H.G.T., Sahala Hutabarat, S., dan Ain, C. 2014. Pengaruh Limbah Cair Tahu Terhadap Kelimpahan Makrobenthos Di Sungai Elo Magelang. Journal of Maquares, 3(4):1-8. 